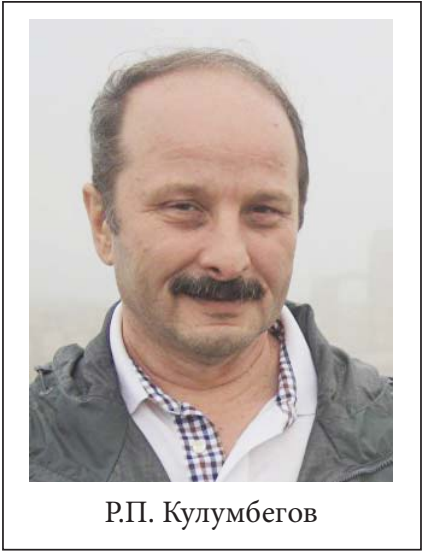

\title{
НАРТОВСКИЙ ЭПОС ОСЕТИН КАК ИСТОЧНИК СВЕДЕНИЙ О ХОЗЯЙСТВЕННОМ БЫТЕ ЕГО СОЗДАТЕЛЕЙ
}

\author{
Р.П. Кулумбегов"
}

Аннотация. В статье рассматривается хозяйственная деятельность героев нартовского эпоса осетин. Обычно эта сторона сказания остается в тени подвигов воиноваристократов. Действительно, земледелие и скотоводство не являются главными занятиями героев эпоса, при этом обнаруживается достаточно свидетельств, чтобы уверенно построить картину бытования этих сфрер хозяйствования в эпическом мире героев Нартиады.

Ключевые слова: нарты, эпос, пахота, пастух, ярмо, обмолот.

Эпическое сказание о нартах характеризуется необычайным разнообразием сюжетов. Сквозной темой героического эпоса является борьба героя с враждебными силами, кажется, что сказители свели все сюжеты Нартовского эпоса именно к этой повествовательной линии. Перечитывая раз за разом тексты сказаний, мы видим, что в тени героических свершений нартов-воинов остался труд нартов-скотоводов и нартов-земледельцев.

Вместе с тем при внимательном анализе сказаний мы понимаем, что осетинский нартовский эпос вобрал в себя большое количество сюжетов, не связанных с темой борьбы с врагами. Есть целый ряд повествований, которые описывают сравнительно мирные приключения нартовских героев, интересные бытовые эпизоды жизни персонажей эпоса.

Реалии повседневной жизни, патриархально-родовое бытие осетин, их хозяйственный быт, праздничная обрядность, их исторические переживания удобнее всего укладывались в эпические формы искусства [2, с. 4]. Неудивительно поэтому, что нартовский эпос воспринимается нами как поэтизированная и франтастическая автобиография народа в древнейший, овеянный мифами и легендами период его жизни. Действительно, какими бы фантастическими не казались события и образы героического эпоса, внимательный анализ и сопоставление с историческими реалиями народной жизни позволяют распознать в них отражение конкретной действительности [1, с. 212].

Так, в эпосе нартовское село, его люди и предметы ничем не отличаются от старой осетинской деревни: здесь мы находим знать, свободных плебеев и рабов [8, с. 11]. Поэтому повествование не могло быть полностью свободным и от описания сцен труда селян.

Например, в тех же «Илиаде» и «Одиссее», являющихся примером эпических полотен, мы видим значительные вкрапления с описанием скотоводства и земледелия. Особенно велика была роль скотоводства: счет ценностям ведется, как правило, в быках, основная масса рабов занята в скотоводстве. У самого Одиссея было несколько десятков пастухов. Велик был перечень видов пастушеской деятельности, в повествовании упоминаются свинопасы и козоводы, пастухи коров и овец и даже старшие пастухи. Таких старших над пастухами мы узнаем по собственным именам Эвмей, Филотий и Мелантий [6, с. 232-248].

В гомеровских сагах в перечне видов хозяйственной деятельности на первом месте стоит скотоводство, однако и земледелие имеет высокий удельный вес. В поэмах говорится о 12 рабынях Одиссея, постоянно занятых помолом зерна, есть упоминание о ручных мельницах и каменных жерновах. Довольно высокого уровня достигла и культура земледельческих работ. В эпосе часто говорится о трижды вспаханном паре, обращается внимание и на глубину вспашки. Так, например, Гомер дает совет пахарям для поднятия паров отдавать преимущество ослам перед волами. Широко использовался плуг, причем особое внимание обращалось на его прочность. Во время уборки участков вождя-басилея жнецы пользовались серпами, другие вязали снопы, дети шли за вязальщиками и подбирали колосья [5, с. 348].

В «Сказаниях о нартах» значительную часть жизни героев занимают военные предприятия, охота и пиры. Понятно, что в реальной жизни люди занимались и повседневным трудом, одни в большей степени, другие в меньшей. В каждом сообществе людей есть и свой привилегированный класс, чурающийся черной работы, но большая часть - это хлебопашцы, скотоводы и ремесленники.

Поэтому в эпосе описывается и обыденная жизнь: нарты пашут землю плугом, отгоняют на выпас скот, выковывают орудия труда и оружие.

Среди домашней живности в описании жизни нартов мы встречаем волов, коров, ослов и свиней. Быки, являясь жертвенными животными на празднествах и тризнах, в сказании связаны с сакральными действиями. Есть в повествовании сюжеты с пастухами, отношение к которым у сказителей уважительное.

Например, важным событием в жизни нартовского общества был выбор пастуха на текущий год. Этот выбор должен был учитывать несколько

“Кулумбегов Роберт Петрович - к. и. н., ст. н. с. Юго-Осетинского научно-исследовательского института. 
аспектов. Во-первых, умение пастуха обращаться с доверенным ему стадом, во-вторых, от него требовалось мужество и военное умение. Ведь стада нартов часто подвергались набегам врагов. Поэтому при необходимости сторожить и пасти стада брались и отмеченные воинской доблестью благородные нарты. В сказании «Батрадз и пестробородый уаиг» мы встречаем описание пиршества, на котором выбирали пастуха: «И тогда старейшие из нартов решили устроить пир, собрать на этот пир весь народ и выбрать пастуха». Тот, кто решался взять на себя эту почетную у нартов обязанность, получал на пиру особое подношение: «три пирога с начинкой из сыра и ляжку быка» [18, с. 251].

От такой чести не отказывались даже такие воины-аристократы, как Сослан и Батрадз. Правда, делают это они не на постоянной основе, а только в случае крайней необходимости. Например, при угрозе гибели скота из-за бескормицы, когда необходимо отогнать стада в дальние земли на тучные пастбища великанов. В этом они похожи на героев гомеровских саг, где экстремальные обстоятельства могут заставить взять посох пастуха и аристократа, и царя [3, с. 8].

Скотоводческая сфера представлена в эпосе довольно обширно. Это и собственные стада, и многочисленная добыча, взятая за пределами страны. Главной ценностью были, конечно же, лошади, только их пород в эпосе насчитывается более десятка. Слова одного из героев эпоса Сослана как нельзя убедительны: «Что будем делать мы, нарты, если падут наши кони?! Ведь человек без коня все равно, что птица без крыльев». Понятно, что ценность лошадей была предопределена их использованием в военных предприятиях. Пехотинцы не пользовались у нартов авторитетом. Так, Сырдон за неимением коня отправился в поход пешком, и за это в пути подвергался насмешкам и издевательствам.

Уход за конями у нартов был особенный. Их кормили поджаренным ячменем, мыли специальным черным мылом. В сказаниях мы находим описание укрощения дикого коня: «Вышел из горной теснины белый конь, прыгнул на него сверху Батрадз. Понес его конь по поляне, но Батрадз схватил его за горло, стиснул и вынудил коня открыть рот. Вдвинул Батрадз ему в рот удила, надел на него уздечку и ловко положил на него седло... а затем натянул поводья и направил коня туда, куда захотел» [18, с. 301].

Лошади применялись только для верховой езды. В гужевой транспорт у нартов впрягались исключительно волы. Только в одном эпизоде мы встречаем фракт того, что в повозку впрягают лошадей. Красавица Акола совершала парадный выезд в крытой повозке, запряженной шестеркой лошадей. Но это исключение объяснялось тем, что Акола не жила в стране нартов.

В сказаниях о нартах земледелие представлено полным циклом: подбор пашен-пахота-сев-боронование-жатва-обмолот-складирование урожая.

Наиболее яркий пример бытования земледелия мы находим в сказании «Чем небожители одарили нарта Сослана» [18, с. 79]. При этом существует несколько вариантов этого сказания, дополняющих друг друга деталями.

Как-то решил небожитель Сафа, покровитель домашнего очага, устроить пир в честь своего воспитанника, юного нарта Сослана. Пригласил к себе Уастырджи - покровителя мужчин-воинов и странников, Уацилла - повелителя громов и урожая, одноглазого Афрсати - властителя благородных зверей, Фалвара, которому послушны овцы, козы и всякий иной мелкий скот, и небесного кузнеца Курдалагона. Среди почетных гостей были повелитель ветров Галагон и владыка вод Донбеттыр.

На пиру каждый из гостей сделал Сослану, а через него и всем нартам, дары. Уастырджи подарил ему меч-фаринк, повелитель благородных зверей Афсати одарил возможностью охотиться в лесах, властитель скота Фалвара научил его заговорам против волков, нападающих на стада.

Другие небожители преподнесли нартам дары, которые можно было с успехом применить в хозяйстве, в данном случае в земледелии. Так, Сафа обращается к Уацилла с просьбой поделиться с нартами хлебными зернами, хранящимися у него в переметной суме, на что получает согласие: «Пусть будет так, вы получите эти зерна. Весной, как только станет согреваться земля, вы будете их сеять на южных склонах гор и холмов. И теми зернами, которые вы соберете осенью, будете кормиться целый год».

В числе дарителей были Галагон и Донбеттыр, повелители природных стихий.

«Когда осенью будете вы веять зерно на току, то нашлю я ветер, унесет он мякину, и останется вам чистое, тяжелое зерно», - сказал Галагон, повелевающий ветрами.

А Донбеттыр дал возможность нартам строить мельницы на своих реках. «Отныне пусть нарты строят мельницы на моих бегущих водах, а я поручу резвым моим дочерям, чтобы они днем и ночью вертели в воде колеса. Вот мой подарок земным людям», - сделал широкий жест властитель водной стихии.

Не остался в стороне и небесный кузнец Курдалагон: «В кузнице своей я изготовлю соху для нартов, и каждой весной они будут ею вспахивать свои пашни».

Таким образом, из семи даров, сделанных нартам, один был связан с военным делом, один дар - с охотой, еще один - со скотоводством, при этом четыре непосредственно с земледелием. Уже один этот фракт свидетельствует о высоком удельном весе этой сферы хозяйствования в нартовском обществе.

В связи с сюжетом Нартовских сказаний о дарах небожителей заслуживают внимания собранные Геродотом мифы о происхождении скифов, в частности, знаменитый миф о получении ими золотых земледельческих орудий (плуга с ярмом) в виде упавших с неба даров, ставших священными реликвиями скифов.

Здесь мы бы хотели обратить внимание не только на простое сходство перечня даров, полученных 
от небес скифами и нартами. Исследователями отмечено даже внешне сходство ряда орудий труда скифов и осетин.

Например, практически идентичны орудие вспашки почвы у скифов, изображение которого на боспорской монете II века н. э. приводит Ю. Краснов, и рала, которым пользовались создатели Нартовского эпоса - осетины [10, с. 123]. Впрочем, общеизвестные скифо-осетинские параллели позволяют исследователям уверенно возводить формирование земледельческой культуры осетин к скифской эпохе [20, с. 44].

В горной Осетии, как и на всем Центральном Кавказе, при пахоте использовалось легкое пахотное орудие типа "рало», имевшее у осетин название дзыбыр // дзывыр. По своей конструкции оно было простым орудием вспашки, имело всего одну железную часть - лемех.

У исследователя осетинского быта Ю. Клапрота мы находим детальное описание пахотного орудия осетин: «Плуг, который употребляют осетины, меньше, чем русский, и имеет следующую форму: а) изогнутый кусок дерева, обе лопасти которого имеют полтора фрута длины и удалены друг от друга лишь на 8 дюймов; б) железный плоский лемех, образующий равносторонний треугольник, приложенный к изогнутому куску дерева и разрыхляющий землю; в) к концу изогнутого куска дерева приделан шест длиной в 6 фрутов, к концу которого припрягают двух быков с ярмом; г) ручка, при помощи которой человек управляет плугом левой рукой, в то время как правой он стегает быков» [9, с. 171].

Бытование рала-дзыбыр было предопределено почвенно-климатическими особенностями горной Осетии. Горцы вспахивали ралом как горные склоны, так и низменности ущелий. Такое пахотное орудие не производило оборот пласта, а только разрыхляло землю. Понятно, что слабый почвенный покров горных почв требовал именно такой технологии, которая бы предохраняла его от эрозии. Слой земли при работе ралом разрезался лемехом и отсыпался боками полоза. Из-за преобладания местных каменисто-щебенистых почв обрабатывать земельные участки было предпочтительно именно таким орудием - легким и маневренным, не требующим большого количества тягловой силы [11, с. 89].

Для земледельца важное значении имеет выбор пашни. Наиболее ценными были участки с южной экспозицией и с ровным профилем - хуссарварс хуымтæ и хъугом. На пиру в честь юного Сослана небожитель Уацилла советует нартам сеять зерно именно «на южных склонах гор и холмов». В эпосе упоминается и наиболее ценная категория земельного надела - Нарты стыр хъугом [14, с. 636].

В сказаниях мы встречаем описание и самого процесса пахоты, причем с использованием определенного агротехнического приема. Так, Сырдон пашет особым способом: «Иу гутонæй дыууæрдæм бакодта сæ хуым - Плугом вспахал пашню вдоль и поперек». Здесь же мы видим и описание сева, который производится вручную, методом разбрасывания зерен [14, с.189]. В перечне зерновых культур, возделываемых нартами, ячмень, пшеница, просо.

Еще одним орудием труда у нартов-пахарей является борона. В сказании «Нарт Дзылау на охоте» сказитель описывает это вспомогательное земледельческое орудие [13, с. 28].

Резвился мальчик на огромном камне,

Он молвил: «Если б ты меня уважил

И смастерил бы борону из дуба...

Своих оленей нарт остановил

И борону из дуба смастерил.

Он сделал это быстро и умело...

Ответил мальчик: «Будь милостив ко мне,

Проехаться позволь на бороне».

Герой исполнил просьбу без запинки

И протянул ребенку хворостинку.

Наиболее распространенным орудием боронования у осетин как в горах, так и на плоскости, являлась борона-волокуша адæ2. Свидетельство широкого применения волокуши осетинами имеется в многочисленных этнографрических источниках. Г.Ф. Чурсин пишет: "Борона имеет обычный вид волокуши и состоит из длинной жерди, к которой на поперечной перекладине прикреплены пучки хвороста [21, с. 21]. В описании Н. Дмитриева отмечено, что «...семена заволакиваются бороною, которая представляет собою не что иное, как довольно тяжелый плетень» [7, с. 9].

Конструкция волокуши была едина на всей территории Осетии. Существовала лишь разница в размерах. Так, в горной полосе из-за небольших размеров участков и сравнительно легких почв борона была небольших размеров, но в предгорьях, с их плотными и тяжелыми почвами, ее делали массивной. В упомянутом выше сказании называется «борона большая», очевидно, предполагается, что использовалась волокуша и меньших размеров.

Волокуша состояла из остова, изготавливаемого из массивной продолговатой доски или бревна, служившего для разбивания комьев и разравнивания вспаханной пашни. На остов волокуши набивали ветки деревьев, к ее остову прикреплялись два шеста (адæджы артmæ), которые скреплялись друг с другом и привязывались к ярму. При работе на него ставили камни или становились подростки, чтобы увеличить тяжесть волокуши для лучшей разбивки комьев земли. О мальчике, стоящем на этом орудии труда, упоминается и в приведенном выше отрывке из сказания «Нарт Дзылау на охоте».

В сказаниях о нартах называется и небесный покровитель, подаривший нартам борону-волокушу Бардуаджы фоырт. Это орудие труда им было преподнесено как дар во время пира [16, с. 264].

Важным элементом организации трудовых процессов в земледелии является тягловая сила. В Oceтии для этого преимущественно использовали волов. В одном из вариантов описания пира в честь юного Сослана указывается, что небожитель Фалвара первым подарил нартам тягловый скот [16, с. 264].

При этом ценились прежде всего пригодные для пахоты волы. Они же могли быть и частью выкупа за невесту - ирæд. Об этом мы встречаем упоминание в сказании «Кадзии и мнимая Сатана», где в качестве выкупа за невесту кадзии отдают колдунье Кулбадаг- 
ус двенадцать пар пахотных волов [16, с. 348]

Особой категорией тягловой силы были т. н. тутырты гуырд галтæ (букв. рожденные в дни Тутыра быки). В сказании «Смерть Батрадза» говорится о том, что по воле небес погибает нарт Батрадз. После этого небесные духи намереваются перевезти тело героя в склеп Софии, однако быки не могут даже сдвинуть повозку с места. Тогда Создатель советует им: «Впрягите в повозку двух быков, рожденных в неделю празднования Тутыра». Впрягли этих быков, и они оказались сильнее двенадцати упряжей, и привезли Батрадза к склепу Софии [17, с. 5.]

После созревания урожая у нартов наступает время жатвы. Эту работу нарты успешно выполняют, даже тогда, когда Бог пытается им в этом помешать. Разгневавшись на нартов, он делает так, что те не могут подойти к своим созревшим нивам. Только они подходят к кромке поля, как зрелые хлеба снова становятся зелеными. Тогда находчивые нарты делают стрелы с раздвоенными наконечниками и пускают их издалека по созревшим хлебам Раздвоенные наконечники срезали часть колосьев - и колосья эти оставались зрелыми [18, с. 483]

Земледельческий цикл у нартов завершается обмолотом урожая. Процесс обмолота описывается в сказании «Нарт Хамыц и Батрадз» [14, с. 485]. Здесь Батрадз мстит за смерть своего отца Хамыца, убивая нарта Бурафарныга и его семерых сыновей. После этого, прибыв к жилищу убитого кровника, Батрадз зовет выглянуть женщин дома Бурафарныга и бросает перед ними отрубленные головы их мужчин.

Заголосили жена Бурафрарныга и его семеро снох и стали клясть Батраза последними словами. Батраз разгневался и погнал перед собой всех восьмерых, мол, хлеб молотить с вами стану, и пригнал их на берег Черного моря. Накосил там терновника, сложил, как для молотьбы, поставил мать посередине, а снох по краям, запряг, как скотину на току, и целый день гонял босыми по колючкам.

Несмотря на то, что этот момент отражает одну из высших форм унижения у нартов, здесь мы видим описание процесса обмолота, принятого в горной полосе Осетии. Правда, обычно для этого использовались быки.

Необходимо отметить, что элемент земледелия как средство унижения встречается не только в осетинском Нартовском эпосе. В истории древнего Рима мы встречаем описание того, как победившие римлян враги унижали их, заставляя проходить под ярмом. Так было в войне с самнитами и армянами. Прохождение под ярмом побежденной римской знати и целого войска было величайшим унижением народа [23, с. 78].

В горной Осетии хлеба обмолачивали преимущественно с помощью крупного рогатого скота (къахæй най). Посреди тока (мус) ставился небольшой столб (мусы къæбæл) с вращающимся на нем обручем. К обручу привязывалась кожаная веревка (рæтæн) длиной в радиус тока (5-8 м). К веревке от одного конца до другого прикреплялись дуги (къæлæттæ) по количеству рабочего скота. В дуги впрягалось, в зависимости от размеров гумна, 5-10 голов крупного рогатого скота и лошадей. Рабочая скотина должна была двигаться вокруг столба справа налево. Указывается в эпосе и наибольший размер тока - это тот, на котором можно молотить на 12 быках [18, с. 266].

В процессе молотьбы урожая в упряжь впрягали быков, коров, буйволов и очень редко лошадей. В эпосе мы встречаем и доброе пожелание людям, работающим на току: «Дзаг мус уm ! - Да полнится зерном ваш ток!»

Упоминаются и другие пожелания: «Дæ бонгуыст къæссайы дзаг уæд! - Чтобы в день вы получали мешок зерна!» или «Бон куырисæй фрылдæр ма банæй кæн, æмæ дын дзы къæссайы дзаг хор цæуæд! - Чтобы от каждого снопа у вас получался мешок ячменя!» [17, с. 465].

Были у нартов и свои меры для обмолоченного зерна. Это «къæсса» (мешок), «къуту» (сапетка), ныккæнд (зерновая яма), къæбиц (кладовая).

Ободряя своего супруга в его желании устроить в голодный год пир нартам, Сатана говорит, что в годы изобилия предусмотрительно отсыпала меру ячменя от каждого мешка про запас в глубокие зерновые ямы и большие кладовые. И имеется теперь у нее «семь кладовых ячменя и семь кладовых пшеницы» [12, с.162].

Несмотря на то, что весь эпос пропитан героической темой, описанием битв, пиров и охоты, даже представители божественного пантеона не чураются связи с хозяйственной деятельностью. Так, небожитель Уастыржи в эпосе и пахарь, и погонщик буйволов на току во время обмолота хлебов [15, с. 253]. Покровитель урожая и природных стихий Уацилла дарит нартам ячмень и пшеницу, его сын подарил нартам деревянное рало-дзывыр, сын Мигъы бардуага - деревянную борону [16, с. 265]. Даже Тутыр - покровитель волков опосредованно участвует в жизни нартов-пахарей, благословляя бычков, рожденных в дни своего праздника.

Практически все авторитетные небожители так или иначе способствуют нартам в их хозяйственной деятельности. Небожители Реком и Мыкалгабырта дарят нартам зерновые злаки. Повелитель ветров Галагон обещает укрывать нивы от жаркого солнца и насылать на них мягкий дождь в засуху, а при ливнях разгонять тучи. Владыка водной стихи Донбеттыр поручает свои дочерям крутить лопасти колес водяных мельниц.

Особое место в Нартовских сказаниях есть у покровителя хлебных злаков Хоралдара и его сына Бурхорали. Последнего убивает нарт Батрадз. В отместку Хоралдар решает наказать нартов. В то время, говорится в эпосе, на стеблях пшеницы, проса и ячменя вырастало по шесть колосьев, и Хоралдар обрывает их все, чтобы оскудели урожаи нартов. Лишь по одному колосу оставляет он на каждом стебле, и то по настоятельной просьбе небожителя Уастырджи [14, с. 204-206].

Образ Хоралдара и его сына Бурхорали исследователи относят к дохристианскому пантеону алан $[19$, с. 184]. Об аланском наследии культа покло- 
нения Хоралдар свидетельствует его бытование и среди балкарцев в несколько искаженной балкарской перегласовке в фрорме «Хардар» [4, с. 74].

Работы в поле не чураются даже великаны. «Адæ2 - иу къахыл, дзывыр - иннæ къахыл - На одной ноге у него борона, на другой рало»,- так описывается труд на пашне великана. При этом он одной рукой держит сапетку с зерном, а другой рукой разбрасывает по полю семена [17, с. 123].

Существует важная особенность любого эпического нарратива - создание идеальной модели социума, идеального образа жизни. Для эпических героев старинных саг характерно стремление к замкнутому циклу деятельности, стандартному набору моделей - пира (и дружеской беседы), войны, охоты [22, с. 185]. Нельзя сказать, что иные виды деятельности полностью чужды для них. Очевидно, создатели эпоса просто не считали необходи- мым широко описывать повседневность бытия, не имеющюю героическую семантику. Действительно, что могло быть интересным для слушателя в описании трудовой деятельности, и так хорошо ему знакомой, другое дело - битвы и пиршества героев-аристократов. Не героика труда, не мирное, хотя и тяжкое угасание человеческой жизни в поте труда, а героика битв захватывает дух и воображение. Звон меча, а не тихий перебор комьев земли под плугом слышится в поэзии наших предков [2, с. 67].

Тем не менее даже в героическом, по сути, повествовании мы находим описание хозяйственной деятельности. При этом обнаруживается достаточно свидетельств, чтобы уверенно построить картину бытования скотоводства и земледелия в эпическом мире нартов. Это - удивительный мир, который населяют не только бесстрашные воины, но и старательные пастухи и умелые пахари.

\title{
ЛИТЕРАТУРА
}

1. Абаев В.И. Нартовский эпос осетин // Избранные труды. Религия. Фольклор. Литература. - Владикавказ: Издательство «Ир», 1990. 639 c.

2. Абаева 3.В. Этюды по нартовскому эпосу. - Цхинвал: Издательство «Ирыстон», 1978. 177 с.

3. Андреев Ю.А. Труд в жизни гомеровских героев // Государство, политика и идеология в античном мире. - Л.: Лениздат, 1990. C.4-13

4. Батчаев В.М. Из истории традиционной культуры балкарцев и карачаевцев. - Нальчик: Эльбрус, 1986.151 с

5. Гомер. Илиада / пер. И. Гнедича. - М.: Эксмо, 2009. 609 с

6. Гомер. Одиссея / пер. В. Жуковского. - М.: Эксмо, 2010. 416 с.

7. Дубровин Н. История войны и владычества русских на Кавказе. - СПб,1871. Том 1, книга 1. - 64 с.

8. Дюмезиль ж. Осетинский эпос и мифология. - М.: Наука, 1976. 273 с

9. Клапрот Ю. Путешествие по Кавказу и Грузии // сб: Осетины глазами русских и иностранных путешественников. - Орджоникидзе, 1967. С. 105-180.

10. Краснов Ю.А. Древнейшие упряжные пахотные орудия. М.: Наука, 1975.182 с.

11. Кулумбегов Р.П. Земледельческие орудия южных осетин // Известия Юго-Осетинского научно-исследовательского ин-

ститута. Цхинвал, 2014. Вып. 40. 400 c.

12. Народное творчество Юго-Осетии. - Цхинвал, 1929. Кн. l. $158 \mathrm{c}$.

13. Нарты. Эпос осетинского народа. - М.: Академия наук CCCP, 1957. 399 c

14. Нарты кадджытæ. - Влад.: Ирыстон, 2005. Книга 3. 711 с.

15. Нарты кадджытæ. - Влад.: Ирыстон, 2007. Кн. 4. 545 с.

16. Нарты кадджытæ.- Влад.: Ирыстон, 2011. Кн. 6. 543 с.

17. Нарты кадджытæ.- Влад.: Ирыстон, 2012. Кн. 7. 617 с.

18. Осетинские нартовские сказания. - Дзауджикау: Госизdam, 1948. 503

19. Чибиров Л.А. Народный земледельческий календарь осетин. - Цхинвал: Ирыстон, 1976. 280 с.

20. Чибиров Л.А.О некоторых скифро-осетинских параллелях в области аграрной религии // Известия ЮОНИИ, Вып.XXV. Тб.: Мецниереба, 1980. С. 43-52.

21. Чурсин Г.Ф. Осетины. Этнографический очерк. - Тифрлис, 1925. $100 \mathrm{c.}$

22. Щербенко М.Ю. Поэмы Гомера как источник о созидательном труде и отношении к нему эллинов того времени // Вестник Нижегородского университета, 2009, № 3. С. 184-189.

23. Эверит Энтони. Возвышение Рима. Создание великой империи. - М.: АCT, 2012. 267 c.

\section{THE OSSETIAN NART EPIC AS A SOURCE OF INFORMATION ON ECONOMIC LIFE}

\section{R.P. Kulumbegov}

\author{
PhD, South-Ossetian Research Institute.
}

Abstract. This article considers the economic activity of the Ossetian Nart epic heroes. Generally, this side of the legend lives in the shadow of warriors-aristocrats' feats.

Indeed, agriculture and cattle breeding are not the heroes' main activities, while there is enough evidence to build a clear picture of the existence of these spheres of husbandry in the epic world of the Nartiade.

Keywords: narts, epos, tillage, shepherd, oxbow, thresh.

\section{REFERENCES}

1. Abaev V.I. Nart epic of Ossetians//Selectas. Religion. Folklore. Literature. - Vladikavkaz: Ir, 1990. 639 p.

2. Abaeva Z.V. Sketches of Nart epic. - Tskhinval: Iryston, 1978. 177 p.

3. Andreev Yu.A. Work in life of Homeric heroes//State, politics and ideology in ancient world. - L.: Lenizdat, 1990. P. 4-13.

4. Batchaev V.M. From traditional culture of Balkarians and Karachays. - Nalchik: Elborus, 1986. 151 p.

5. Homer. Illiad / translated by I.Gnedich. - M.: Eksmo, 2009. 609 p. 6. Homer. Odyssey/translated by V.Zhukovsky. - M.: Eksmo, 2010. 416p. 7. Dubrovin N. Dubrovin N. F. The history of war and Russian domination in Caucasus. - Spb,1871. Vol 1, book 1. 64 p.

8. Dumezil G. Ossetian epos and mythology. - M.:Nauka, 1976. 273 p. 9. Klaprot Yu. A trip to the Caucasus and Goergia//Ossetia through the eyes of Russian and foreign travelers. Orjonikidze, 1967 pp.105-180.

10. Krasnov. Yu. A. The most ancient instruments for harness and tillage. - M.: Nauka, $1975.182 p$.

11. Kulumbegov R.P. Agricultural tools of the South Ossetians//Izvestiya of South Ossetian research institute. Tskhinval, 2014. 40-400 p.
12. Folk art in South Ossetia. - Tskhinval, 1929. Vol I. $158 p$ 13. Narts. Epos of Ossetian nation. - M.:Akademiya nauk USSR, 1957. $399 p$.

14. Narty kaddjyta. - Vlad:Iryston, 2005. Book 3. 711p.

15. Narty kaddjyta. - Vlad:Iryston, 2007. Book 4. 545 p.

16. Narty kaddjyta. - Vlad:Iryston, 2011. Book 6. 543 p.

17. Narty kaddjyta. - Vlad:Iryston, 2012. Book 7. 617 p.

18. Ossetian tales of Narts. - Vladikavkaz: Gosizdat, 1948. 503 p

19. Chibirov L.A. National agrarian calendar of Ossetians - Tskhinval: Iryston, 1976. 280 p.

20. Chibirov L.A. Some scythian-ossetian parallels in agrarian religion// Izvestiya of the South Ossetian Scientific Research Institute. 1980,Pub.XXV.P.43-52

21. Chursin G.F. Ossetians. Ethnographic sketch. - Tiflis, 1925-100 p. 22. Scherbenko M.Yu. Homer's poems as a source on productive labour and hellenes' attitude to IT INVestnik of University of Nizhni Novgorod,2009, №3. Pp.184-189.

23. Anthony Everitt. The rise of Rome. - M.:AST,2012.267 p. 